\title{
Estimation of hydraulic properties of subglacial till from ploughmeter measurements
}

\author{
Urs H. Fischer, ${ }^{1}$ Neal R. Iverson, ${ }^{2 *}$ Brian Hanson, ${ }^{3}$ Roger LeB. Hooke, ${ }^{2}$ Peter Jansson ${ }^{4}$ \\ ${ }^{1}$ Versuchsanstalt für Wasserbau, Hydrologie und Glaziologie, ETH-Zentrum, CH-8092 Zürich, Switzerland \\ ${ }^{2}$ Department of Geology and Geophysics, University of Minnesota, Minneapolis, Minnesota 55455-0219, U.S.A. \\ ${ }^{3}$ Center for Climatic Research, Department of Geography, University of Delaware, Newark, Delaware 19716, U.S.A. \\ ${ }^{4}$ Department of Physical Geography, Stockholm University, S-106 91 Stockholm, Sweden
}

\begin{abstract}
Force variations on a "ploughmeter" and fluctuations in subglacial water pressure have been measured in the same borehole at Storglaciären, Sweden, to investigate hydraulic properties of the basal till layer. A strong inverse correlation of the pressure and force records, in conjunction with a significant time lag between the two signals, suggests that pore-water pressures directly affect the strength of the till. Variations in subglacial water pressure result in potential gradients across the water-till interface at the bottom of the borehole that drive pressure waves downwards through the till layer when the borehole water level is high and back upwards when the water level is low. Analysis of the propagation velocity of this pressure wave indicates that the hydraulic diffusivity of Storglaciären till is in the range $1.9-3.6 \times 10^{-6} \mathrm{~m}^{2} \mathrm{~s}^{-1}$, in good agreement with estimates obtained in the laboratory. Hydraulic conductivity values associated with these diffusivities are between $10^{-9}$ and $10^{-8} \mathrm{~m} \mathrm{~s}^{-1}$ and thus are well within the range of values for other glacial tills.
\end{abstract}

\section{INTRODUCTION}

Several instruments have been designed to study the in-situ mechanical properties and deformation of till beneath glaciers. Among the most successful of these have been ploughmeters, steel rods that are driven vertically into the till bed through boreholes and that bend elastically as they are dragged through the till during basal motion (Fischer and Clarke, 1994, 1997; Hooke and others, 1997). Bending of the rod is measured with strain gauges, allowing the force on the instrument to be determined and the mechanical properties of the till to be estimated.

In this study, we use the record from a ploughmeter to obtain an in-situ estimate of the hydraulic diffusivity and conductivity of till beneath Storglaciären. A consistent lag between water-pressure fluctuations measured in a borehole and the force on the ploughmeter is interpreted to reflect the time required for the water-pressure wave to propagate through the pores of the till to the depth of the ploughmeter. The change in pore-water pressure at depth affects the till strength and thereby changes the force on the instrument. Standard diffusion theory is used to calculate the hydraulic diffusivity of the till from this lag, and laboratory measurements of the till compressibility are used to estimate the conductivity from the diffusivity. Our results are then compared with those of other studies.

\footnotetext{
* Present address: Department of Geological and Atmospheric Sciences, Iowa State University, Ames, Iowa 50011-3210, U.S.A.
}

\section{CHARACTERISTICS OF STORGLACIÄREN}

Storglaciären (Fig. 1) is a small polythermal valley glacier, situated in the Kebnekaise Massif of northern Sweden. A transverse bedrock ridge, or riegel, divides the ablation area into two parts with a smaller overdeepening on the downglacier side and a larger overdeepened basin on the upglacier side. Crevasses over the riegel, along the sides and over the headwall at the up-glacier end of this overdeepening constitute primary input points for water to the englacial and subglacial drainage system of the glacier. Tracer studies (Hooke and others, 1988; Seaberg and others, 1988; Hock and Hooke, 1993; Hooke and Pohjola, 1994) have demonstrated that water passing through the overdeepening emerges in Nordjåkk, a stream that normally carries a negligible sediment load. Water that enters the glacier by way of crevasses and moulins over the riegel exits through Sydjåkk stream which is much dirtier. The difference in sediment concentration is taken to indicate that water in Sydjåkk stream moves a considerable distance along the bed, while that in Nordjåkk is largely englacial.

From observations of the dirt content of the two streams, it is clear that there is a fundamental difference in the drainage system of the lower and upper parts of the ablation area. The section down-glacier from the riegel drains largely subglacially through a well-defined conduit system (Hock and Hooke, 1993). Water pressures in boreholes vary significantly in response to changes in the input rate of water at the glacier surface (Hooke and others, 1989). In addition, the surface velocity of the glacier was found to correlate well with variations in subglacial water pressure (Jansson, 1995). In contrast, the main drainage system through the overdeepening up-glacier from the riegel is englacial (Hooke 


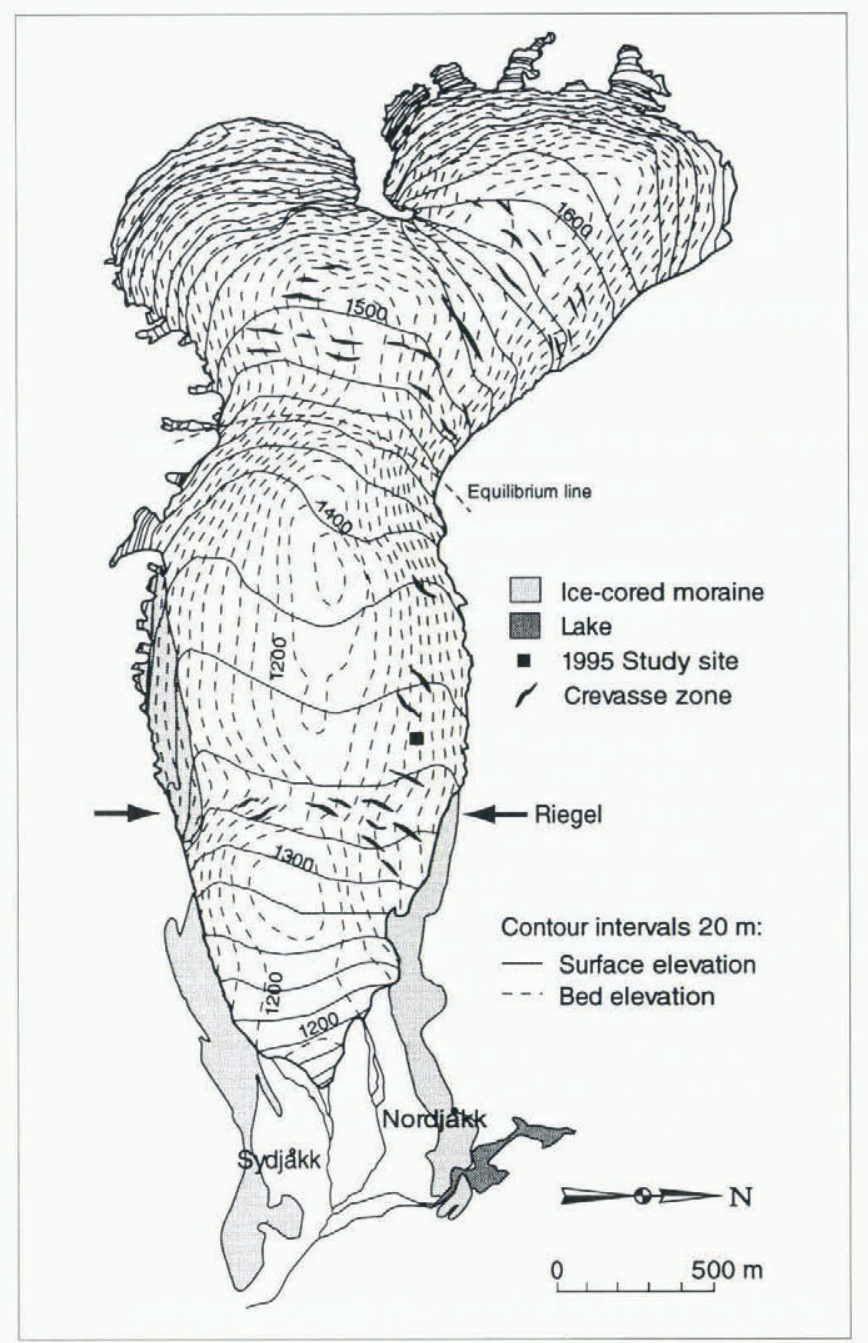

Fig. 1. Map of Storglaciären showing surface and bed topography, locations of crevasse zones through which water enters the englacial and subglacial drainage system, and the location of the 1995 study site.

and Pohjola, 1994). Although there is a subsidiary drainage system between the ice and the bed acting parallel to the englacial system, most of the water appears to pass through this overdeepened section englacially and does not affect the base of the glacier. Water pressures were found to be relatively constant and averaged $80-90 \%$ of the overburden pressure (Hooke and others, 1989).

Electrical resistivity measurements (Brand and others, 1987), seismic studies (unpublished data of J. Paetz), direct sampling through boreholes (unpublished data of N. R. Iverson), borehole-video investigations (Pohjola, 1993) and measurements using instruments installed at the bottoms of boreholes (Iverson and others, 1994, 1995; Hooke and others, 1997) suggest that throughout the overdeepening the glacier is underlain by a discontinuous layer of till, $0.2-0.5 \mathrm{~m}$ thick. Hooke (1991) suggested that this till layer is not flushed from the glacier sole, because of the lack of significant subglacial drainage. It is beneath this part of the glacier where the measurements discussed here were made.

\section{OBSERVATIONS}

As part of a study to describe the rheology of deforming till beneath Storglaciären (Hooke and others, 1997), 15 holes were drilled through the glacier roughly $350 \mathrm{~m}$ up-glacier from the riegel during July 1995 (Fig. 1). At this site, the ice was $\sim 125 \mathrm{~m}$ thick. With one exception, all boreholes drained at levels between 8 and $65 \mathrm{~m}$ below the glacier surface as the drill presumably intersected conduits in the englacial drainage system. The one hole that did not drain remained full of water even when the drill reached the bed. Water pressures recorded in three of these holes tracked each other closely and thereby are consistent with the idea that the boreholes are interconnected through a network of englacial conduits (Hooke and Pohjola, 1994).

Two holes were instrumented with ploughmeters to measure the strength of the subglacial till. Figure 2 shows roughly 70 days of observations for ploughmeter 95PL-1 and pressure transducer $95 \mathrm{P}-1$, both recorded in the same borehole. We estimate that this ploughmeter was inserted $\sim 0.13 \mathrm{~m}$ into the basal till. Variations in the ploughmeter signal (Fig. 2a) are inversely correlated with fluctuations in subglacial water pressure (Fig. 2b) such that high forces experienced by the ploughmeter coincide with low water pressures and vice versa. The force on the ploughmeter could have been influenced by the velocity with which the ploughmeter was dragged through the till (Fischer and Clarke, 1994). To check this possibility, the velocity of a stake drilled into the surface of the glacier near our study site was measured over the same time period (Fig. 2c) and showed no correlation to the ploughmeter record. Assuming that measured variations in surface velocity reflect variations in the rate at which ice slides over the till (as opposed to rates of till deformation) (Iverson and others, 1995; Hooke and others, 1997), this lack of correlation between force on the ploughmeter and glacier sliding suggests that the force was not influenced significantly by the rate at which the ploughmeter moved through the till.

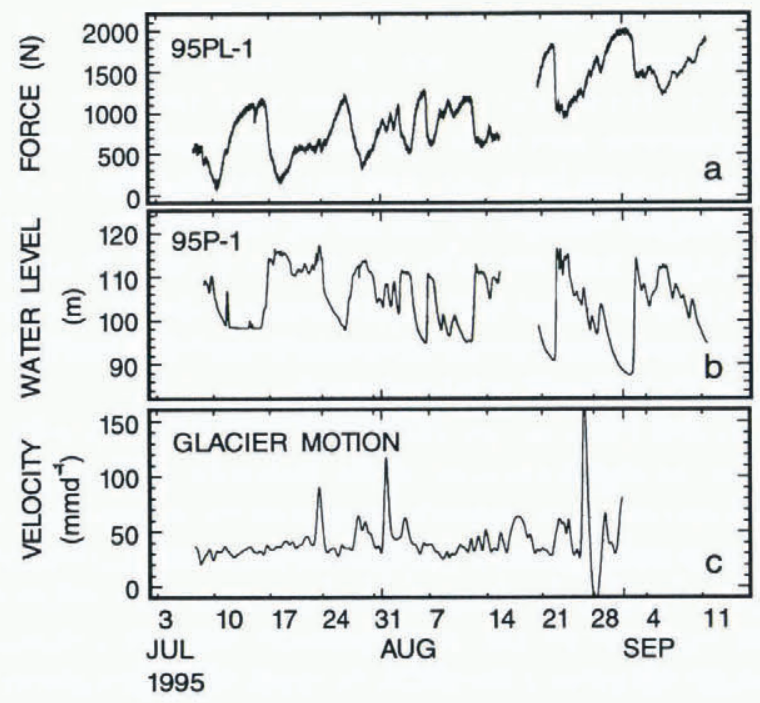

Fig. 2. Time series of (a) force applied to the lowermost section of the ploughmeter (95PL-1), (b) subglacial water pressure $(95 P-1)$ and (c) surface velocity.

\section{STRENGTH OF THE DEFORMING TILL}

The strength of a deforming granular material can be derived from the familiar Mohr-Coulomb failure criterion (Mitchell, 1976, p. 283; Head, 1994, p. 204)

$$
\tau=c+P_{\mathrm{e}} \tan \phi
$$

which relates the yield strength $\tau$ at which a material begins to deform irrecoverably to the cohesion $c$, the effective pres- 
sure $P_{\mathrm{e}}$ (the difference between the overburden pressure and the pore-water pressure) and the angle of internal friction $\phi$. Once deforming, the sediment may either dilate or contract, but eventually the sediment volume and friction angle become steady (Skempton, 1985) and the sediment is said to reach its residual state. Cohesion becomes negligible in the residual state (Mitchell, 1976, p.313; Head, 1994, p. 210), so Equation (1) reduces to

$$
\tau_{\mathrm{r}}=P_{\mathrm{e}} \tan \phi_{\mathrm{r}}
$$

where $\phi_{\mathrm{r}}$ is the residual friction angle. According to Equation (2), the residual strength $\tau_{\mathrm{r}}$ of the deforming sediment increases with increasing effective pressure or decreasing pore-water pressure. If subglacial water pressure is taken as a proxy indicator for pore-water pressure, Equation (2) is consistent with the observed inverse relation of water pressure and ploughmeter response (Fig. 2a and b), which suggests that increased water pressures weaken the till, resulting in less force on the ploughmeter.

With knowledge of the pore-water pressure in the till layer, the overburden pressure (from the ice thickness) and the angle of internal friction, we can calculate the residual strength of Storglaciären till from Equation (2). This residual strength can further be used to compute the force that the ploughmeter experiences as it is dragged through the till. If this calculated force is in good agreement with that measured in the field (Fig. 2a), we have support for our assumption that the Mohr-Coulomb condition (Equation (2)) adequately describes the strength of Storglaciären till. The measured mean subglacial water pressure (Fig. 2b) is about $1.05 \mathrm{MPa}$ (water-column height of $105 \mathrm{~m}$ ) for the interval 5 July-17 August, so the effective pressure is $\sim 0.1 \mathrm{MPa}$ at the base of the $\sim 125 \mathrm{~m}$ deep borehole. Then with $\phi_{\mathrm{r}}=25.5$ (Hooke and others, 1997), Equation (2) yields a residual strength $\tau_{\mathrm{r}} \approx 48 \mathrm{kPa}$. For comparison, the force $F$ plotted in Figure 2a is related to $\tau_{\mathrm{r}}$ by

$$
F=\frac{4 a(2+\pi) \tau_{\mathrm{r}}}{z_{\mathrm{g}}} \int_{z_{\mathrm{g}}}^{z}\left(z^{\prime}-z_{\mathrm{g}}\right) \mathrm{d} z^{\prime}
$$

(Fischer and Clarke, 1994, equations (14) and (15)). Here, $a$ is the radius of the ploughmeter $(16 \mathrm{~mm}), z_{\mathrm{g}}$ is the distance from the tip of the ploughmeter to the point where the strain gauges were bonded $(0.1 \mathrm{~m})$ and $z$ denotes the depth to which the ploughmeter is immersed in the till layer $(0.13 \mathrm{~m})$. The integral term sums the bending moments applied to the end of the ploughmeter as it is dragged through the till. It is these moments that are sensed by the strain gauges bonded to the ploughmeter. The mean value of $F$ for the interval 5 July-17 August from Figure 2a is $\sim 800 \mathrm{~N}$, so $\tau_{\mathrm{r}}$ derived from the ploughmeter readings is $\sim 49 \mathrm{kPa}$, in good agreement with the value calculated from the known $P_{\mathrm{e}}$ and friction angle.

\section{ESTIMATION OF HYDRAULIC PROPERTIES}

Having now shown that the ploughmeter results are consistent with those based on other data, we proceed to use these results to estimate the hydraulic properties of the till. Assuming that ploughmeter 95PL-1 and pressure transducer $95 \mathrm{P}-1$ were installed in a borehole which is not well connected to the subglacial drainage system, fluctuations in the borehole water level reflect variations in the water pressure in the englacial conduit system. When the water level rises, the water at the base of the borehole becomes over- pressurized with respect to the water in the pore space of the underlying till layer. Similarly, upon a drop in water level, there is a local under-pressurization at the base of the hole. A potential gradient therefore exists across the watertill interface at the bottom of the borehole that reverses temporally in accordance with the water-level fluctuations. As a result, we expect that a water pressure wave is initiated at the base of the borehole and that this wave migrates downwards through the underlying till layer when the water level is high and back upwards when the water level is low. Fluctuations in pore-water pressure in the till layer should lag those recorded with the pressure transducer in the borehole as it takes time for the pressure waves to propagate through the till. Because pore-water pressures directly affect the strength of the till (Equation (2)), variations in the force response of the ploughmeter should also lag those in subglacial water pressure. Calculation of the cross-correlation between the record of ploughmeter 95PL-1 (Fig. 2a) and the record of pressure transducer 95P-1 (Fig. 2b) for different time shifts ranging from -2 days to +2 days (Fig. 3 ) suggests that this time lag is $\sim 0.22$ days. Note that this and any of the time-series analyses that follow are based on the interval 5 July-17 August, thus avoiding any mathematical difficulties associated with the data gap.

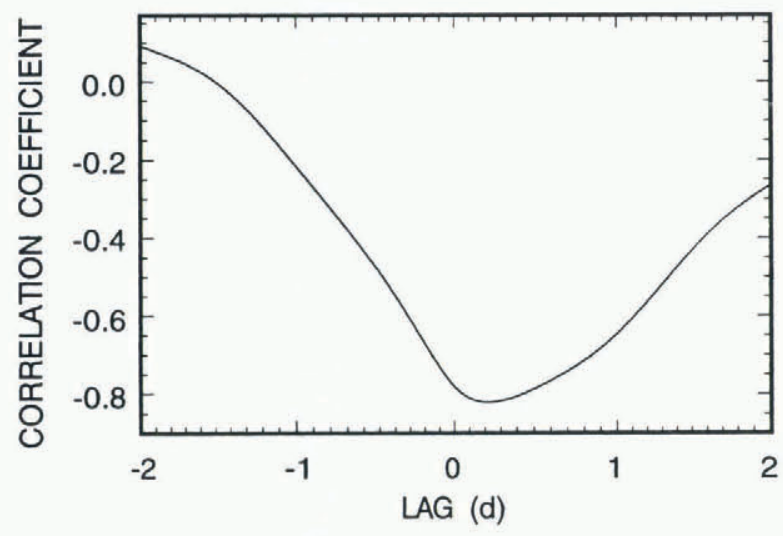

Fig. 3. Cross-correlation between the force recorded by ploughmeter 95PL-1 (Fig. 2a) and the subglacial water pressure recorded by pressure transducer $95 \mathrm{P}-1$ ( Fig. 2b) for different time shifts.

We follow the analyses of Fountain (1994) and Hubbard and others (1995) to investigate quantitatively the permeability of subglacial till on the basis of the speed of waterpressure waves as they propagate through it. A hypothetical arrangement is to represent the glacier bed as a semi-infinite solid with the $z$ axis positive downward (Fig. 4). A steady water pressure is assumed at infinity and the pressure variation at the base of the borehole is treated as a boundary condition at the till-water interface. If this driving pressure varies as a harmonic function of time, we can apply results from standard diffusion theory (e.g. Carslaw and Jaeger, 1959) to relate the propagation velocity of the pressure wave to the frequency of the initiating pressure fluctuations and the hydraulic diffusivity of the till through which the wave passes. The pressure fluctuations are propagated into the till layer with velocity (Carslaw and Jaeger, 1959, p. 66)

$$
v=\frac{z}{t}=\sqrt{2 \omega D}
$$

where $D$ is the hydraulic diffusivity of the till and $\omega$ is the angular frequency of the periodic boundary condition. 


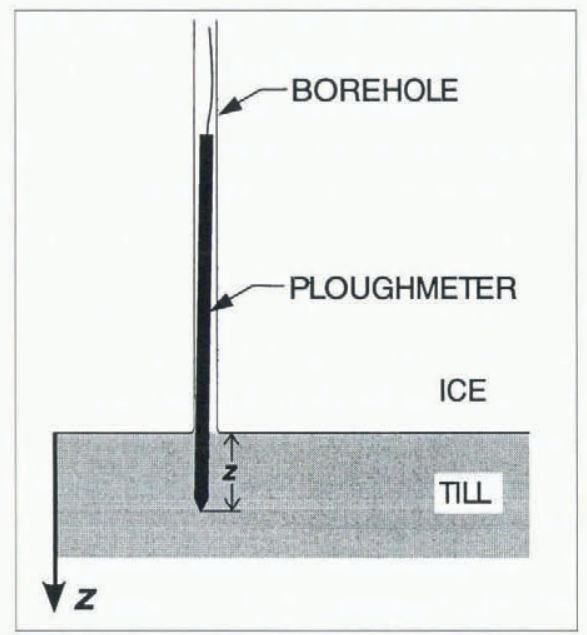

Fig. 4. Definition sketch for Equation (4) showing the glacier bed represented as a semi-infinite solid.

Here, $t$ is the time at which the pressure maxima (or minima) arrive at a distance $z$ from the bottom of the borehole (Fig. 4). Solving Equation (4) for $D$ gives

$$
D=\frac{z^{2}}{2 \omega t^{2}} \text {. }
$$

The hydraulic diffusivity is a parameter that couples transmission and storage properties of the till, expressed as the ratio of hydraulic conductivity $K$ to specific storage $S_{\mathrm{s}}$ (Freeze and Cherry, 1979, p. 61)

$$
D=\frac{K}{S_{\mathrm{s}}} .
$$

Physically, $S_{\mathrm{s}}$ represents the volume of water released from storage by a unit volume of till when a unit decline in hydraulic head occurs. A decrease in hydraulic head induces a decrease in pore-water pressure, allowing the water to expand, and an increase in effective pressure, causing the till to compact. The amount of water that is released from storage can therefore be described by (Freeze and Cherry, 1979, p. 59)

$$
S_{\mathrm{s}}=\rho_{\mathrm{w}} g(\alpha+n \beta)
$$

where $\rho_{\mathrm{W}}$ is the density of water, $g$ is the acceleration due to gravity, $n$ is porosity and $\alpha$ and $\beta$ are compressibility coefficients for the porous medium and the fluid, respectively. In the geotechnical literature, the compressibility $\alpha$ of a granular material is expressed as the change in voids ratio de caused by the change in effective pressure $\mathrm{d} P_{e}$ (Freeze and Cherry, 1979, p. 54)

$$
\alpha=-\frac{\mathrm{d} e /\left(1+e_{0}\right)}{\mathrm{d} P_{\epsilon}}
$$

where $e_{0}$ is the initial voids ratio. The value of $\alpha$ is smaller at smaller voids ratios, because equal increments in effective pressure result in progressively smaller decreases in voids ratio as the most efficient (dense) packing geometry for the till is approached. The value of $\alpha$ also depends on the grainsize of the material. Values of $\alpha$ range from $10{ }^{10} \mathrm{~Pa}^{-1}$ in coarse sand and gravel to $10^{-6} \mathrm{~Pa}^{-1}$ in clay and silt (Freeze and Cherry, 1979, p. 55).

The dominant periods in the variations of the force on the ploughmeter (Fig. 2a) and the subglacial water pressure (Fig. 2b) are of several days. Both time series were analyzed for their frequency content by taking the Fourier transform (Press and others, 1992, p. 501) and the power spectral densi-

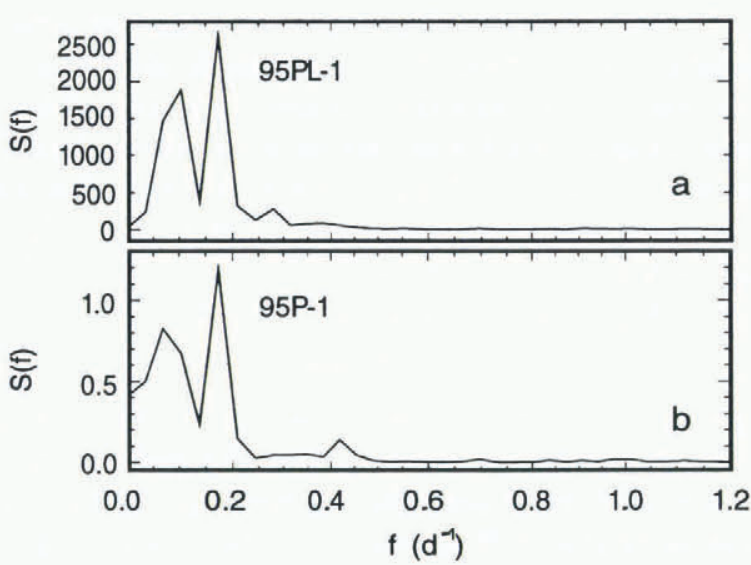

Fig. 5. Power spectral density functions for (a) the ploughmeter record shown in Figure $2 a$ and $(b)$ the subglacial water-pressure record shown in Figure 2b. Pre-processing of the time series included removing the trend and offset by subtracting out a regression line followed by padding the resulting data with zeros up to the next power of 2 .

ties were estimated using the periodogram method (Press and others, 1992, p. 550). We see that for both the force- and pressure-power spectral density functions (Figure $5 \mathrm{a}$ for the 95PL-1 data and Figure 5b for the 95P-1 data) most of the energy is contained in the frequency range $0.05-0.2 \mathrm{~d}^{-1}$. For these low frequencies, the two power spectra agree quite well; two dominant peaks that are present in both spectra at frequencies 0.175 and $0.09 \mathrm{~d}^{-1}$ indicate that the ploughmeter clearly responds to water-pressure variations with periods of 5.7 and 11.1 days, respectively. Pressure- and ploughmeter-force variations with frequencies larger than $\sim 0.2 \mathrm{~d}^{-1}$ are of significantly smaller amplitudes. Furthermore, the two spectra do not agree as well in this higher frequency range; a noticeable peak in the power spectrum of the 95P-1 data (Fig. 5b), which indicates a water-pressure forcing with a frequency of $0.42 \mathrm{~d}^{-1}$, is not apparent in the response of the ploughmeter (Fig. 5a).

In the following, we will assume that the depth to which the pressure wave has to propagate corresponds to the insertion depth of the ploughmeter. Our thinking is that it is only when the pressure wave reaches the tip of the instrument that the till becomes weakened within a sufficiently thick layer for the ploughmeter to experience reduced forces. Clearly, the ploughmeter response scales with the integral of the force along its length (Fischer and Clarke, 1994). However, as indicated earlier, the ploughmeter response is not sensitive to high-frequency water-pressure fluctuations, suggesting that pressure fluctuations felt at smaller depths do not affect the ploughmeter, which supports the above assumption. Therefore, substituting $z=0.13 \mathrm{~m}$ (insertion depth of ploughmeter; Fig. 4), $t=0.22$ days (lag from the cross-correlation analysis; Fig. 3 ) and $\omega=0.65-1.27 \times 10^{-5} \mathrm{~s}^{-1}$ (corresponding to frequencies ranging from 0.09 to $0.175 \mathrm{~d}^{-1}$, where $\omega=2 \pi$ times the frequency; Fig. 5) into Equation (5), we compute hydraulic diffusivity values $D$ for Storglaciären till between $1.9 \times 10^{6}$ and $3.6 \times 10^{-6} \mathrm{~m}^{2} \mathrm{~s}^{-1}$.

Consolidation tests conducted on a basal till sample collected from a trench dug into the margin of Storglaciären (Baker and Hooyer, 1996) provide the data necessary to determine $\alpha$ (Equation (8)). In these tests, the effective pressure on water-saturated till in a ring-shear device (Iverson and others, 1997) was increased, and the consequent reduction in specimen thickness was measured as pore water was 


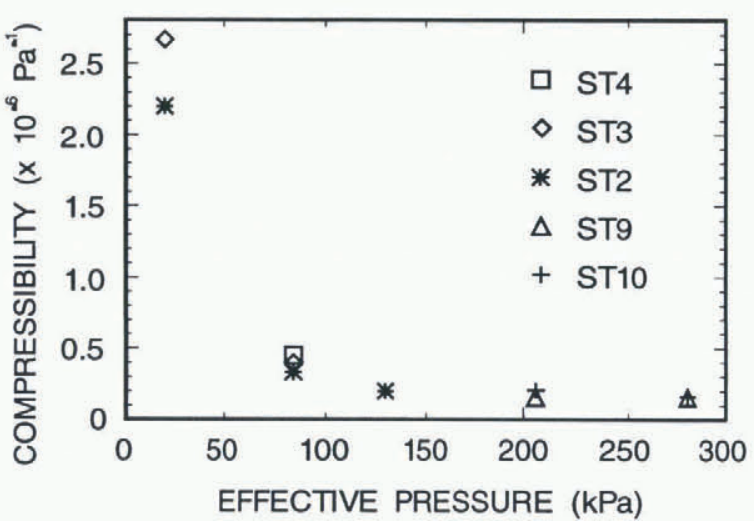

Fig. 6. Results from five different consolidation tests (ST4, ST3, ST2, ST9 and ST10) conducted on a basal till sample from Storglaciären.

squeezed out of the specimen through permeable platens. The value of de was determined from the total reduction in thickness after consolidation had stopped and from measurements of the voids ratio at the conclusions of the tests. Measured values of the compressibility are reduced with increasing effective pressure (Fig. 6), owing to the decrease in the voids ratio with effective pressure. The two largest values of compressibility in Figure 6 resulted from very high initial voids ratios, which are unlikely subglacially. Considering, therefore, only the other values, compressibilities of $1-5 \times 10^{-7} \mathrm{~Pa}^{-1}$ are probably most appropriate for Storglaciären till.

We can now approximate the range of hydraulic conductivities associated with the inferred diffusivities by calculating values of specific storage from Equation (7). For $\beta=44 \times 10^{10} \mathrm{~Pa}^{-1}$ and $n=0.22-0.24$ (Iverson and others, 1997), we obtain $S_{\mathrm{s}}=1-5 \times 10^{3} \mathrm{~m}^{-1}$. Hence, from Equation (6), the resulting hydraulic conductivity range for Storglaciären till is $K=10^{-9}-10^{-8} \mathrm{~m} \mathrm{~s}^{-1}$.

\section{CONGLUDING DISGUSSION}

In this paper, we have shown how hydrological parameters necessary to characterize pore-water flow through subglacial till can be determined from the propagation velocity of pressure waves through this material. We have based our analysis on standard diffusion theory and have therefore been able to relate the time lag between the fluctuations in water level recorded in a borehole and the force variations, as measured with a ploughmeter, to the hydraulic diffusivity and hydraulic conductivity of the subglacial till layer. We can compare our in-situ estimates to those obtained previously from laboratory studies using a Storglaciären till sample (Table 1). From consolidation tests, Iverson and others (1997) were able to derive hydraulic diffusivity values in the range $D=1.5-3.8 \times 10^{-6} \mathrm{~m}^{2} \mathrm{~s}^{-1}$. This result is in excellent agreement with that determined in this study. However, earlier tests with a falling-head permeameter resulted in hydraulic conductivity values between $K=1.3 \times 10^{7}$ and $4.7 \times 10^{-6} \mathrm{~m} \mathrm{~s}^{-1}$ (Iverson and others, 1994; Baker and Hooyer, 1996), which are one to two orders of magnitude larger than the values obtained here. While our estimates of hydraulic conductivities are well within the range of conductivity values for typical glacial tills $\left(10^{-12}-10^{-6} \mathrm{~m} \mathrm{~s}^{-1}\right.$; Freeze and Cherry, 1979, p. 29), those from the laboratory study are typical of Darcian flow through a silty sand. The laboratory result is therefore con-
Table 1. Reported values of hydraulic conductivity for subglacial tills

\begin{tabular}{|c|c|c|}
\hline $\begin{array}{l}\text { Hydraulic } \\
\text { conductivity } \\
\mathrm{m} \mathrm{s}^{-1}\end{array}$ & Location & Source \\
\hline $10^{7}-10^{6}$ & $\begin{array}{l}\text { Storglaciaren } \\
\text { (laboratory study) }\end{array}$ & $\begin{array}{l}\text { Iverson and others (1994, } \\
\text { Baker and Hooyer (1996) }\end{array}$ \\
\hline $10^{-7}-10^{-4}$ & $\begin{array}{l}\text { South Cascade Glacier } \\
\text { (in-situ study) }\end{array}$ & Fountain (1994) \\
\hline $10^{-7}-10^{4}$ & $\begin{array}{l}\text { Haut Glacier d'Arolla } \\
\text { (in-situ study) }\end{array}$ & Hubbard and others (1995) \\
\hline $10^{-1}-1$ & $\begin{array}{l}\text { Trapridge Glacier } \\
\text { (in-situ tests) }\end{array}$ & $\begin{array}{l}\text { Stone and Clarke (1993), } \\
\text { Stone and others (1997) }\end{array}$ \\
\hline $10^{4}-1$ & $\begin{array}{l}\text { Gornergletscher } \\
\text { (in-situ tests) }\end{array}$ & Iken and others (1996) \\
\hline $10^{9}$ & $\begin{array}{l}\text { Trapridge Glacier } \\
\text { (in-situ tests) }\end{array}$ & Waddington and Clarke 1995 \\
\hline $10^{12}-10^{6}$ & & Freeze and Cherry (1979) \\
\hline
\end{tabular}

sistent with the finding that till from beneath the margin of Storglaciären is a clay-poor sediment and consists largely of silts and sands $4 \%$ clay, $21 \%$ silt and $75 \%$ sand; Baker and Hooyer, 1996).

The falling-head permeameter tests were conducted on a sample of till from below the riegel, whereas the borehole utilized for our tests was above the riegel. Thus, the significant difference between the laboratory and in-situ estimates of hydraulic conductivity could be due to a difference in composition and texture of the till above and below the riegel. Water flowing through the well-defined subglacial conduit system in the section of Storglaciären down-glacier of the riegel may have flushed out clay particles. As a result, this "coarse" subglacial till layer is likely to have a higher hydraulic conductivity than the till beneath the overdeepening up-glacier from the riegel, where the fine material has not been removed by water flow, because of the lack of significant subglacial drainage. Alternatively, our low insitu estimates of hydraulic conductivity may also partly be a result of active shear deformation of the sediment laver beneath Storglaciären (Iverson and others, 1995; Hooke and others, 1997). Deformation of subglacial sediments can result in the orientation of particles within the sediment parallel to the direction of principal strain (Murray and Dowdeswell, 1992. This particle alignment leads to anisotropic hydraulic conductivities as water through-flow will be facilitated parallel to the plane of deformation typically in the downglacier and cross-glacier directions) and retarded perpendicular to this plane. In contrast, particle alignments in a remolded sample in the laboratory are presumably random. Thus, the hydraulic conductivity in a remolded sediment sample might be expected to be larger than that normal to the shearing direction in a deforming sediment layer.

Most previous in-situ estimates of the hydraulic conductivity of subglacial material differ significantly from ours (Table 1). By analyzing average water levels and natural variations in water levels observed in boreholes drilled to the bed of South Cascade Glacier, Fountain (1994) derived hydraulic conductivity values for the subglacial material $\left(10^{-7}-10^{-4} \mathrm{~m} \mathrm{~s}^{-1}\right)$ that are between one and five orders of magnitude larger than our estimates. These high values were interpreted as being indicative of subglacial water flow along the ice-sediment interface in addition to within the sediment. Analyses of the propagation velocity and the attenua- 
tion of diurnal pressure waves passing through the basal material between a subglacial channel and a transverse profile of boreholes at Haut Glacier d'Arolla (Hubbard and others, $1995)$ yielded equally high conductivity values. However, this latter study further indicated that the subglacial sediment layer is characterized by a systematic transverse variation in hydraulic conductivity as it appeared that values decreased exponentially with distance from the channel. This finding suggested that fine material had been removed from sediments more efficiently closer to the subglacial channel than further away and therefore supports our interpretation that subglacial water flow in the conduit system of the lower ablation area of Storglaciären has the capacity to flush out clay particles. Response tests in boreholes that were connected to the subglacial drainage system on Trapridge Glacier (Stone and Clarke, 1993; Stone and others, 1997) and on Gornergletscher (Iken and others, 1996) resulted in hydraulic conductivity values that are typical of Darcian flow through coarse sands or gravels $\left(10^{-4}-1 \mathrm{~m} \mathrm{~s}^{-1}\right)$. Stone and Clarke (1993) demonstrated that the observed hydraulic responses of the connected water system are consistent with a highly transmissive and water-saturated macroporous zone overlain by glacier ice and resting on a sediment substrate having a low permeability. In contrast, Waddington and Clarke (1995) concentrated attention on the unconnected water system beneath Trapridge Glacier and, again using the response of water-filled boreholes, obtained in-situ determinations of the hydraulic conductivity $\left(1.35-7.0 \times 10^{-9}\right.$ $\mathrm{m} \mathrm{s}^{-1}$ ) which are similar to values found in this study.

In summary, our estimate of the till conductivity is significantly smaller than those from laboratory tests on a Storglaciären till sample and from some other in-situ estimates of the conductivity of till beneath other glaciers (Table 1). However, it is likely that these other measurements have been made on till that has been washed by subglacial water flow. Our results are consistent with in-situ measurements made in hydraulically isolated parts of glacier beds where water flow and consequent winnowing are expected to be less effective.

\section{ACKNOWLEDGEMENTS}

We thank T. Dahlgren, E. M. Grace and F. Neidhart for their energetic assistance during our field program. This research was funded by the U.S. National Science Foundation (grant OPP-92-24209) and the Swedish Natural Sciences Research Council. M. Sharp, who read an earlier version of this manuscript, provided some valuable comments. We also acknowledge D. MacAyeal for a critical review of this paper.

\section{REFERENGES}

Baker, R.W. and T.S. Hooyer. 1996. Multiple till layers beneath Storglaciären. Stockholms Univ... Naturgeogra. Instit.. Forskningsrapport 103, 25-29.

Brand, G., V. Pohjola and R. LeB. Hooke. 1987. Evidence for a till layer beneath Storglaciären, Sweden, based on electrical resistivity measurements. F. Glaciol., 33 (115), 311-314.
Carslaw, H. S. and J. C. Jaeger. 1959. Conduction of heat in solids. Second edition. Oxford, Clarendon Press.

Fischer, U. H. and G. K. C. Clarke. 1994. Ploughing of subglacial sediment. 7. Glaciol., 40 (134), 97-106.

Fischer, U. H. and G. K. C. Clarke. 1997. Clast collision frequency as an indicator of glacier sliding rate. 7. Glaciol., 43 (145), 460-466.

Fountain, A. G. 1994. Borehole water-level variations and implications for the subglacial hydraulics of South Cascade Glacier, Washington State, U.S.A. J. Glaciol., 40 (135), 293-304.

Freeze, R. A. and J. A. Cherry. 1979. Groundwater. Engelwood Cliffs, NJ, Prentice-Hall.

Head, K. H. 1994. Manual of soil laboratory testing. Second edition. London, Pentch Press.

Hock, R. and R. LeB. Hooke. 1993. Evolution of the internal drainage system in the lower part of the ablation area of Storglaciären, Sweden. Geol. Soc. Am. Bull., $105(4), 537-546$.

Hooke, R. LeB. 1991. Positive feedbacks associated with erosion of glacial cirques and overdeepenings. Geol. Soc. Am. Bull., 103 (8), 1104-1108.

Hooke, R. LeB. and V. A. Pohjola. 1994. Hydrology of a segment of a glacier situated in an overdeepening, Storglaciären, Sweden. 7. Glaciol., 40 (134), $140-148$.

Hooke, R. LeB., S. B. Miller and J. Kohler. 1988. Character of the englacial and subglacial drainage system in the upper part of the ablation area of Storglaciären, Sweden. 7. Glaciol., 34 (117), 228-231.

Hooke, R. LeB., P. Calla, P. Holmlund, M. Nilsson and A. Stroeven. 1989. A 3 year record of seasonal variations in surface velocity, Storglaciären, Sweden. J. Glaciol., 35 (120), 235-247.

Hooke, R. LeB., B. Hanson, N. R. Iverson, P. Jansson and U. H. Fischer. 1997. Rheology of till beneath Storglaciären, Sweden. 7. Glaciol., 43 (143), $172-179$.

Hubbard, B. P., M.J. Sharp, I. C. Willis, M. K. Nielsen and C. C. Smart. 1995. Borehole water-level variations and the structure of the subglacial hydrological system of Haut Glacier d'Arolla, Valais, Switzerland. f. Glaciol., 41 (139), 572-583.

Iken, A., K. Fabri and M. Funk. 1996. Water storage and subglacial drainage conditions inferred from borehole measurements on Gornergletscher, Valais, Switzerland. f. Glaciol., 42 (141), 233-248.

Iverson, N. R., P. Jansson and R. LeB. Hooke. 1994. In-situ measurement of the strength of deforming subglacial till. f. Glaciol., 40 (136), 497-503.

Iverson, N. R., B. Hanson, R. LeB. Hooke and P. Jansson. 1995. Flow mechanism of glaciers on soft beds. Science, 267 (5194), 80-81.

Iverson, N. R., R. W. Baker and T. S. Hooyer. 1997. A ring-shear device for the study of till deformation: tests on tills with contrasting clay contents. Quat. Sci. Rev., 16 9), 1057-1066.

Jansson, P. 1995. Water pressure and basal sliding on Storglaciären, northern Sweden. J. Glaciol., 41 (138), $232-240$.

Mitchell, J. K. 1976. Fundamentals of soil behavior. New York, etc., John Wiley and Sons.

Murray, T. and J. A. Dowdeswell. 1992. Water throughflow and the physical effects of deformation on sedimentary glacier beds. f. Geophys. Res., 97 (B6), 8993-9002.

Pohjola, V. A. 1993. TV-video observations of bed and basal sliding on Storglaciären, Sweden. 7. Glaciol., 39 (131), 111-118.

Press, W. H., S. A. Teukolsky, W.T. Vetterling and B. P. Flannery. 1992. Numerical recipes in FORTRAN: the art of scientific computing. Second edition. Cambridge, Cambridge University Press.

Seaberg, S. Z., J. Z. Seaberg, R. LeB. Hooke and D. W. Wiberg. 1988. Character of the englacial and subglacial drainage system in the lower part of the ablation area of Storglaciären, Sweden, as revealed by dye-trace studies. 7. Glaciol., 34(117), 217-227.

Skempton, A. W. 1985. Residual strength of clays in landslides, folded strata, and the laboratory. Géotechnique, 35 (1), 3-18.

Stone, D. B. and G. K. C. Clarke. 1993. Estimation of subglacial hydraulic properties from induced changes in basal water pressure: a theoretical framework for borehole-response tests. 7. Glaciol., 39 (132), 327-340.

Stone, D. B., G. K. C. Clarke and R. G. Ellis. 1997. Inversion of boreholeresponse test data for estimation of subglacial hydraulic properties. $\mathcal{F}$. Glaciol., 43 (143), 103-113.

Waddington, B. S. and G. K. C. Clarke. 1995. Hydraulic properties of subglacial sediment determined from the mechanical response of waterfilled boreholes. F. Glaciol., 41 (137), 112-124. 